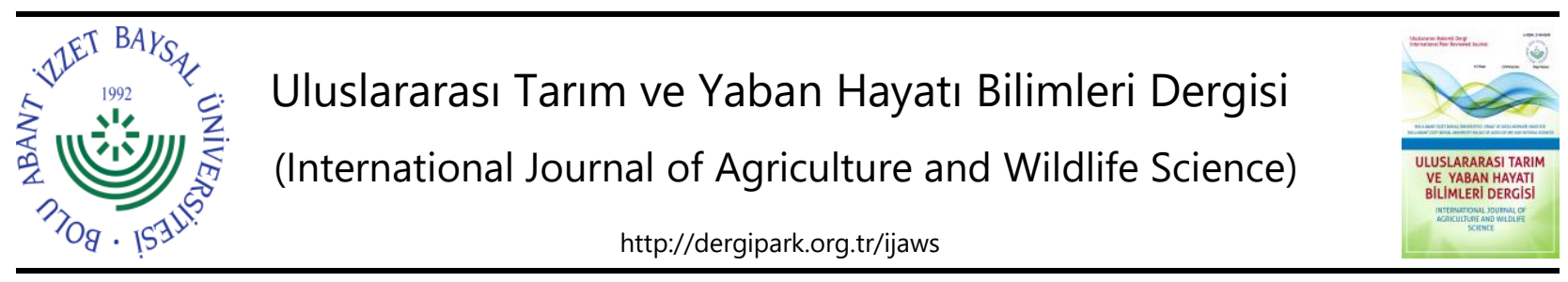

Araştırma Makalesi

\title{
Geç Olum Süresine Sahip Bazı Tatlı Sorgum (Sorghum bicolor var. saccharatum (L.) Mohlenbr.) Genotiplerinin Biyokütle Verimi ve Yem Kalitesinin Belirlenmesi
}

\author{
Abdullah Öktem* ${ }^{*}$, Ayşe Gülgün Öktem $\mathbb{D}^{\mathbb{D}}$, Dicle Demir \\ Harran Üniversitesi, Ziraat Fakültesi, Tarla Bitkileri Bölümü, Şanlıurfa
}

Geliş tarihi (Received): 30.04.2021

Kabul tarihi (Accepted): 04.07.2021

\begin{abstract}
Anahtar kelimeler:
Tatlı sorgum, biyokütle, NDF, $A D F, A D L$

*Sorumlu yazar

aoktem@harran.edu.tr

Özet. Araştırmada geç olgunlaşma süresine sahip tatlı sorgum genotiplerinin biyokütle verimi ve yem kalite ögelerinin belirlenmesi amaçlanmıştır. Deneme tesadüf blokları deneme deseninde üç tekerrürlü olarak 2019 yılı ana ürün yetiştirme sezonunda Harran Ovası koşullarında yürütülmüştür. Çalışmada Brandes, Corina, Dale, Grassi, M81-E, P1579753, Ramada, Rio Roma, Smith, Theis, Topper 76-I, Topper 76-II, Tracy, UNL-Hybrid 3 ve Gülşeker gibi 16 adet geç olgunlaşma süresine sahip tatlı sorgum genotipleri kullanılmıştır. Araştırma sonuçlarına göre tatlı sorgum genotiplerinde gözlenen çiçeklenme süresi 77.6 ile 108.0 gün, bitki boyu $250.80 \mathrm{~cm}$ ile $476.30 \mathrm{~cm}$, sap kalınlığı $19.55 \mathrm{~mm}$ ile $27.99 \mathrm{~mm}$ arasında değişmiştir. Sap oranı \%74.72 ile \%91.49, yaprak oranı \%6.23 ile \%20.98, salkım oranı \%1.70 ile \%7.65 arasında bulunmuştur. Tatlı sorgum genotiplerinin biyokütle verimi 7714.3 ile $16380.9 \mathrm{~kg} \mathrm{da}^{-1}$, kuru madde verimi 2521.95 ile $5599.35 \mathrm{~kg} \mathrm{da}^{-1}$, ham kül oranı \%6.54 ile \%10.1 arasında değişmiştir. NDF (Neutral Detergent Fiber) değerleri \%55.35 ile \%43.68, ADF (Acid Detergent Fiber) değerleri \%27.09 ile \%34.76, ADL (Acid Detergent Lignin) değerleri \%5.51 ile \%7.59, hemiselüloz değerleri \%15.59 ile \%20.59, selüloz oranı ise \%21.31 ile \%27.17 arasında bulunmuştur. Biyokütle verimi, kuru madde verimi, NDF ve ADF değerleri göz önüne alındığında M81-E, Theis, Tracy ve Dale tatlı sorgum genotiplerinin yem değerlerinin diğerlerine göre daha iyi olduğu görülmüştür. Tatlı sorgum bitkisinin yem kaynağı olarak kullanılabileceği ve GAP bölgesinde ve benzer iklim koşullarında adaptasyon kabiliyetinin yüksek olduğu belirlenmiştir.
\end{abstract}

\section{Determination of Biomass yield and Forage Quality of Some Late Maturated Sweet Sorghum (Sorghum bicolor var. saccharatum (L.) Mohlenbr.) Genotypes}

\section{Keywords:}

Sweet sorghum, biomass, NDF, ADF, ADL

\begin{abstract}
In the research, it was aimed to determine the biomass yield and forage quality components of some late maturated sweet sorghum genotypes. The experiment was conducted in a randomized block design with three replications in the 2019 main crop growing season under Harran Plain conditions. In the study, 16 late-maturated sweet sorghum genotypes such as Brandes, Corina, Dale, Grassi, M81-E, P1579753, Ramada, Rio Roma, Smith, Theis, Topper 76-I, Topper 76-II, Tracy, UNL-Hybrid 3 and Gülşeker were used. According to the results of the research, the flowering period in sweet sorghum genotypes varied between 77.6 and 108.0 days, plant height between $250.80 \mathrm{~cm}$ and $476.30 \mathrm{~cm}$, stem diameter between $19.55 \mathrm{~mm}$ and $27.99 \mathrm{~mm}$. The stem ratio values were found between $74.72 \%$ and $91.49 \%$, leaf ratio $6.23 \%$ and $20.98 \%$, panicle ratio between $1.70 \%$ and $7.65 \%$. The biomass yield of sweet sorghum genotypes ranged from 7714.3 to $16380.9 \mathrm{~kg} \mathrm{da}-$ 1 , dry matter yield from 2521.95 to $5599.35 \mathrm{~kg} \mathrm{da}^{-1}$, crude ash ratio from $6.54 \%$ to $10.1 \%$. NDF (Neutral Detergent Fiber) values were found between $55.35 \%$ and $43.68 \%$. ADF (Acid Detergent Fiber) values were between $27.09 \%$ and $34.76 \%$, ADL (Acid Detergent Lignin) values between $5.51 \%$ and $7.59 \%$, hemicellulose values between $15.59 \%$ and $20.59 \%$, cellulose values between $21.31 \%$ and $27.17 \%$. Considering the biomass yield, dry matter yield, NDF and ADF values, it was seen that the feed values of M81-E, Theis, Tracy and Dale sweet sorghum genotypes were better than the others. It has been determined that the sweet sorghum plant has high adaptability in the GAP region and can be used as a feed source in similar climatic conditions.
\end{abstract}




\section{GiRiş}

Tatlı sorgum bitkisi (Sorghum bicolor var. saccharatum (L.) Mohlenbr.) Poaceae familyasından tek yıllık bir bitkidir. C4 bitkisi olması nedeniyle fotosentez etkinliği yüksektir. Doğu ve Kuzey Afrika orjinli olan bitki güçlü ve hızlı büyüme özelliğine sahiptir. Etkili, derinlere inen ve güçlü kök yapısı ile yaprakları ve gövdesi üzerindeki mum tabakası sayesinde bitkinin kuraklığa dayanaklığı artmaktadır. Suyu daha efektif kullanan tatlı sorgum bitkisi su tasarrufu sağlayarak diğer bitkilerin yetişemediği marjinal alanlarda bile yetişebilme imkânı bulmaktadır. Tatı sorgum bitkisi diğer bitkilere göre kullandığı birim su miktarına karşılık daha fazla kuru madde üretmektedir. Toprak seçiciliği fazla olmayan tatlı sorgum bitkisi her türlü toprakta yetişebilmektedir. Hastalık ve zararlılara karşı da dayanıklılı̆ı yüksektir (Öktem ve Öktem, 2018).

Tatlı sorgum bitkisi boyu 5 m'ye kadar uzayabilen bir bitkidir. Erken olgunlaşan genotiplerin sap uzunluğu geç olgunlaşan genotiplerinden daha kısa olmaktadır. Gövde boğum ve boğum aralarından oluşmaktadır. Bitkinin sapı içerisindeki özsuyu tatlı olup, \%7.0-18.9 arasında değişen şeker intiva etmektedir (Öktem ve ark., 2018). En fazla şeker miktarı sap kısmında bulunmakta olup, bitki özsuyu fruktoz, glikoz, sakkaroz, arabinoz, sukroz, galaktoz gibi 14'ten fazla şeker türünü içermektedir. Sapta bulunan bu şekerli özsuyu fermantasyona tabii tutularak biyoetanol üretilmektedir (Öktem ve ark., 2018). Şekerli özsuyu içeren bitki kısımları hayvan beslenmesinde kullanıldığında yem değeri de artmaktadır.

Tatlı sorgum bitkisinin taneleri ve sapındaki şıradan elde edilen şeker ve pekmez gıda maddesi olarak insan beslenmesinde kullanılabilmektedir. Sorgum unundaki protein glüten barındırmadığından, tahıla alerjisi olan kişiler unundan rahatlıkla faydalanma imkânı bulabilmektedirler.

Bitkinin yeşil aksamı yeşil yem, kuru yem ve silaj olarak hayvan beslenmesinde kullanılabilmektedir. Bitki boyunun uzun olması ve birim alanda çok fazla sayıda kardeş meydana getirmesi nedeniyle birim alan biyokütle ve kuru madde verimi diğer yem bitkilerinden daha fazla olmaktadır.

Taneleri kesif yem yapılarak hayvan beslenmesinde kullanılabilir. $100 \mathrm{~g}$ tohumda $4.40-21.10 \mathrm{~g}$ protein, 55.60 - $75.20 \mathrm{~g}$ nişasta, 1.00 - $3.40 \mathrm{~g}$ lif, 2.10 - $7.60 \mathrm{~g}$ yağ ve 1.30 - $3.30 \mathrm{~g}$ kül içermektedir (Abah ve ark., 2020).

Tatlı sorgum bitkisinin toplam ağırlığının, \%70-75'i saptan, \%10-15'i yapraktan, \%10'u kökten ve \%7'si tane kısmından oluşmaktadır. Bu oranlar genotipe, kültürel uygulamalara, toprak yapısına, verilen gübre miktarına, ekim sıklığına bağlı olarak değişmektedir (Grassi, 2021).

Dünya'da tatlı sorgum'un yem bitkisi olarak kullanılmasına karşın, Türkiye'de yeni tanınmaya başlamıştır. Tatlı sorgum bitkisinin ülkemizde ve bölgemizde yaygınlaşması ile yem açığı kapatılarak hayvansal üretime ve ülke ekonomisine katkı sağlanabilecektir.

Araştırmada geç olgunlaşma süresine sahip bazı tatlı sorgum genotiplerinin yem olarak kullanılabilme potansiyellerinin ortaya çıkarılması, GAP bölgesi ana ürün koşullarında adaptasyon kabiliyetlerinin, biyokütle verimi ve yem kalite ögelerinin belirlenmesi amaçlanmıştır.

\section{MATERYAL VE METOT}

Çalışma Harran Üniversitesi Ziraat Fakültesi Eyyübiye Araştırma ve Uygulama alanında 2019 yılında ana ürün yetiştirme koşullarında yürütülmüştür. Denemede bitki materyali olarak geç olgunlaşma süresine sahip Brandes, Corina, Dale, Grassi, M81-E, P1579753, Ramada, Rio, Roma, Smith, Theis, Topper 76-I, Topper 76-II, Tracy, UNLHybrid-3 ve Gülşeker gibi 16 adet tatlı sorgum genotipi kullanılmıştır. Gülşeker yerli ve standart çeşit olup, diğerleri Amerika Birleşik Devletlerinden temin edilmiştir.

Deneme alanı toprağı bölgede geniş yayılım gösteren Harran toprak serisinde bulunmaktadır. Bu çeşit toprakların ana materyali alüvyon olup killi ve derin profilli düz ve düze yakın topraklardır. Tipik kırmızı profilleri kil tekstürlü ve bütün profil oldukça kireçlidir (Dinç ve ark., 1988). Deneme alanından alınan toprak örneklerinde yapılan bazı fiziksel ve kimyasal analiz değerleri Çizelge 1'de verilmiştir. Çizelge 1'den deneme alanına ait toprak özellikleri incelendiğinde; organik madde ve azot bakımından fakir, potasyum miktarı yüksek, alkali yapıda, tuzluluk düzeyinin düşük ancak kireç oranının yüksek olduğu görülmektedir.

Şanlıurfa ili Güneydoğu Anadolu iklim bölgesinde bulunmaktadır. Kısmen Akdeniz ikliminin de etkisi görülebilir. Yazları sıcak ve kurak kışları ılık bir iklime sahiptir. Yaz aylarında yağış miktarı yok denecek kadar az olup hava nispi nemi \%50'nin altındadır. Denemenin yürütüldüğü aylara ait bazı iklim değerlerinin yer aldığı Çizelge 2'de görüldüğü gibi Haziran ve Temmuz aylarında sıcaklık $40{ }^{\circ} \mathrm{C}^{\prime}$ nin üzerine, Ağustos ayında ise $45^{\circ} \mathrm{C}^{\prime}$ nin üzerine çıkmıştır. Bu aylarda hava nisbi nemi ise \%30 civarında gerçekleşmiştir. Haziran ayında $8.9 \mathrm{~mm}$ yağış görülürken, Temmuz ve Ağustos aylarında ise hiç yağış kaydedilmemiştir. Tatlı sorgum bitkisi yetiştiriciliğini kısıtlayıcı iklimsel bir unsur oluşmamış, yapılan sulama ile bitkiler sorunsuz olarak yetiştirilmiştir. 
Deneme tesadüf blokları deneme deseninde 3 tekerrürlü olarak yürütülmüştür. Deneme alanı, Nisan ayı içerisinde pullukla 20-25 cm derinlikte sürülmüş, goble disk ile kesekler parçalandıktan sonra tapan çekilerek toprak düzleştirilmiş ve ekime uygun tohum yatağı hazırlanmıştır.

Denemede her parsel $5 \mathrm{~m}$ uzunluğunda ve 4 sıradan oluşmuş olup, sıra arası $70 \mathrm{~cm}$ sıra üzeri ise $15 \mathrm{~cm}$ olacak biçimde daha önce hazırlanan sırtlara her ocağa 2'şer tohum bırakılarak 2-4 cm derinliğe 24 Nisan 2019'da elle ekim yapılmıştır.

Çizelge 1. Deneme alanına ait bazı toprak özellikleri.

Table 1. Some soil characteristics of the experimental area.

\begin{tabular}{|c|c|c|c|c|c|c|c|c|c|}
\hline $\begin{array}{l}\text { Derinlik } \\
\text { (cm) }\end{array}$ & $\begin{array}{l}\text { Hacim ağırlığı } \\
\left(\mathrm{g} \mathrm{cm}^{-3}\right)\end{array}$ & $\begin{array}{l}\text { Organik } \\
\text { madde (\%) }\end{array}$ & $\begin{array}{l}\text { Kum } \\
\text { (\%) }\end{array}$ & $\begin{array}{l}\text { Silt } \\
\text { (\%) }\end{array}$ & $\begin{array}{l}\text { Kireç } \\
\text { (\%) }\end{array}$ & pH & $\begin{array}{l}\mathrm{N} \\
\left(\mathrm{kg} \mathrm{da}^{-1}\right)\end{array}$ & $\begin{array}{l}\mathrm{P}_{2} \mathrm{O}_{5} \\
\left(\mathrm{~kg} \mathrm{da}^{-1}\right)\end{array}$ & $\begin{array}{l}\mathrm{K}_{2} \mathrm{O} \\
\left(\mathrm{kg} \mathrm{da}^{-1}\right)\end{array}$ \\
\hline $0-30$ & 1.37 & 1.2 & 7 & 34 & 59 & 7.3 & 2.5 & 2.7 & 128 \\
\hline $30-60$ & 1.40 & 0.8 & 17 & 25 & 58 & 7.2 & 1.2 & 2.0 & 90 \\
\hline $60-90$ & 0.6 & 0.6 & 20 & 21 & 59 & 7.2 & 0.6 & 1.7 & 81 \\
\hline
\end{tabular}

Çizelge 2. Şanlıurfa'da 2019 tatlı sorgum büyüme dönemindeki aylık bazı iklim verileri.

Table 2. Some monthly climatic data in Şanlıurfa during the 2019 sweet sorghum growth period.

\begin{tabular}{lllllll}
\hline Aylar & $\begin{array}{l}\text { Ortalama } \\
\text { sıcaklık }\end{array}$ & $\begin{array}{l}\text { En yüksek } \\
\text { sıcaklık } \\
\left({ }^{\circ} \mathbf{C}\right)\end{array}$ & $\begin{array}{l}\text { En düşük } \\
\text { sıcaklık } \\
\left.\mathbf{(}{ }^{\circ} \mathbf{C}\right)\end{array}$ & $\begin{array}{l}\text { Ortalama } \\
\text { nisbi nem } \\
\mathbf{( \% )}\end{array}$ & $\begin{array}{l}\text { Ortalama } \\
\text { güneşlenme } \\
\text { süresi (saat) }\end{array}$ & $\begin{array}{l}\text { Toplam yağış } \\
\text { miktarı } \\
(\mathbf{m m})\end{array}$ \\
\hline Nisan & 14.4 & 26.8 & 5.9 & 67.0 & 7.6 & 97.4 \\
Mayıs & 25.2 & 40.3 & 10.1 & 35.8 & 11.1 & 7.3 \\
Haziran & 30.7 & 44.1 & 18.5 & 30.6 & 11.8 & 8.9 \\
Temmuz & 31.7 & 42.3 & 19.7 & 29.6 & 12.4 & 0.0 \\
Ağustos & 32.8 & 45.8 & 20.7 & 29.3 & 11.3 & 0.0 \\
Eylül & 27.9 & 39.5 & 15.9 & 30.3 & 10.4 & 0.2 \\
Ekim & 22.9 & 36.2 & 11.3 & 44.9 & 7.4 & 45.1 \\
Kasım & 12.8 & 18.7 & 8.4 & 72.5 & 5.9 & 44.9 \\
\hline
\end{tabular}

Şanlıurfa Meteoroloji Müdürlüğü 2019 Yılı Bülteni (Anonim, 2019).

Ekimden sonra yağmurlama sulama yapılarak çıkış sağlanmıştır. Ekimden önce taban gübresi olarak $5 \mathrm{~kg} \mathrm{da}^{-1}$ saf fosfor ve $5 \mathrm{~kg} \mathrm{da}^{-1}$ saf azot uygulanmıştır. Bitkiler 40-50 cm'ye ulaştığında ise $15 \mathrm{~kg} \mathrm{da}^{-1}$ saf azot üst gübre olarak verilmiştir (Girgin, 2012). Çimlenme gerçekleştikten sonra bitkiler 15-20 cm iken tekleme ardından el çapası ve daha sonra da traktör çapası yapılmıştır. Illk traktör çapası bitkiler $15-25 \mathrm{~cm}$ arasında iken, 2. traktör çapası ise bitkiler $40 \mathrm{~cm}$ iken yapılmıştır. İhtiyaç duyuldukça mekanik olarak yabancı otlarla mücadele yapılmıştır. Çıkıştan sonra bitkilerin su ihtiyacına göre 10-12 gün arayla sulama yapılmıştır.

Araşıırmada çiçeklenme süresi, bitki boyu, sap kalınlığı, sap oranı, yaprak oranı, salkım oranı, biyokütle verimi ve kuru madde verimi gibi özellikler yanında ham kül oranı, NDF (Neutral Detergent Fiber), ADF (Acid Detergent Fiber), ADL (Acid Detergent Lignin), hemiselüloz ve selüloz oranı gibi kalite ögeleri de incelenmiştir.

Bitkilerin hasadı, her bir genotipin olgunlaşma süresi dikkate alınarak süt olum-sarı olum döneminde yapılmıştır (Geren ve ark., 2019). Hasatta, parsel başından $0.5 \mathrm{~m}$ ve kenardaki birer sıra kenar tesiri olarak bırakıldıktan sonra ortadaki 2 sıra hasat edilmiştir $\left(2 \times 0.7 \times 4=5.6 \mathrm{~m}^{2}\right)$. Hasat sırasında, her parselde ortadaki 2 sıradan 10 bitki tesadüfü olarak seçilmiş ve bitki boyu, sap kalınlığı, sap oranı, yaprak oranı ve salkım oranı gibi özelliklerinde ölçümler bu örnek bitkiler üzerinde yapılmıştır.

Kuru madde oranı değerini belirlemek için her bir genotipi temsil edecek ve tesadüfen seçilen $500 \mathrm{~g}$ yaş bitki örnekleri kurutma dolabında $65-70{ }^{\circ} \mathrm{C}^{\prime}$ de en az 48 saat süreyle ağırlıkları sabitleşinceye kadar kurutulmuştur. Kuru madde oranları ile biyokütle değerleri çarpılarak kuru madde verimleri hesaplanmıştır. Kurutulan örnekler öğütüldükten sonra $575 \pm 25^{\circ} \mathrm{C}^{\prime}$ de kül fırınında yakılmış ve ağırlık kaybından kül içeriği saptanmıştır (Sluiter ve ark., 2008). Öğütülen örneklerden 0.5'er gram kullanılarak NDF, ADF ve ADL analizleri ANKOM Fiber Analyzer Cihazı kullanılarak gerçekleştirilmiştir (Ankom, 2004). \%Selüloz = \%ADF - \%ADL formülüyle, \%Hemiselüloz = \%NDF - \%ADF formülleri ile hesaplanmıştır (Van Soest ve ark., 1991).

Denemede elde edilen veriler varyans analizine tabi tutulmuş, ortalamalar arasındaki farklılıklar ise \%5 seviyesinde DUNCAN testine göre belirlenmiştir (Efe ve ark., 2000). 


\section{BULGULAR VE TARTIŞMA}

\section{Çiçeklenme Süresi (gün)}

Varyans analiz sonuçlarına göre Harran Ovası ana ürün koşullarında denenen tatlı sorgum genotipleri arasında çiçeklenme süresi bakımından \%1 düzeyinde istatiksel olarak önemli farklılık olduğu tespit edilmiştir ( $\mathrm{P} \leq 0.01)$.

Çizelge 3'te görüldüğü gibi çiçeklenme süresi 77.6 ile 108.0 gün arasında değişmiş olup, ortalama çiçeklenme süresi değeri 95.6 gün olarak saptanmıştır. Çiçeklenme süresi 77.6 gün ile Gülşeker çeşidinde en düşük, 108 gün ile Topper 76-I çeşidinde en yüksek olarak belirlenmiştir. Brandes, M81-E, Smith, Topper 76-I, Tracy ve UNLHybrid-3 genotipleri 100 günün üzerinde çiçeklenme süresine sahip vejetasyon süresi en uzun genotipler olarak belirlenmiştir. Gülşeker dışında diğer genotiplerin tamamı 80 günün üzerinde çiçeklenme göstermişlerdir.

Çiçeklenme süresinin uzun olması vejetasyon süresinin ve olgunlaşmanın uzamasına neden olmakta bu durum verime olumlu yansımaktadır. Genellikle uzun vejetasyon süresine sahip genotipler güneş ışı̆ı̆ından, topraktaki su ve besin elementlerinden daha fazla süre yararlandıkları için kuru madde üretimleri de fazla olmakta ve verim yükselmektedir.

Bulgulara benzer olarak Reddy ve ark. (2005) farklı tatlı sorgum genotiplerin \%50 çiçeklenme gün sayılarını 69 ile 88 gün arasında, Avcı ve ark. (2018) ise çiçeklenme gün sürelerini 87.1 ile 92.8 gün arasında bulmuşlardır. Samarth ve ark. (2018) ise bulgularımızdan daha düşük olarak 73 ile 77 gün arasında değişen çiçeklenme süresi tespit etmişlerdir.

\section{Bitki Boyu (cm)}

Denenen tatlı sorgum genotipleri arasında bitki boyu açısından 0.01 seviyesinde istatiksel olarak önemli farklılık olduğu tespit edilmiştir $(P \leq 0.01)$. En düşük bitki boyu Theis çeşidinde $250.8 \mathrm{~cm}$ olarak gözlenmiştir. Bitki boyunun en fazla olduğu değer ise $476.3 \mathrm{~cm}$ ile M81-E çeşidinde bulunmuştur (Şekil 1). Bitki boyu ortalama değeri ise $326.37 \mathrm{~cm}$ olarak görülmüştür (Çizelge 3). M81-E çeşidine en yakın bitki boyu değeri ise $411.53 \mathrm{~cm}$ ile P1579753 genotipinde gözlenmiştir. M81-E, P1579753, Grassi, Roma, Smith ve UNL-Hybrid-3 genotiplerinin bitki boyu 250 cm'nin üzerinde bulunmuştur. Bitki boyunun yüksek olması birim alan biyokütle miktarını artırmaktadır. Olgunlaşma süresi fazla olan genotiplerin bitki boyu değerleri de daha yüksek olmaktadır.

Araştırma sonuçlarını destekler nitelikte Salman ve Budak (2015) tatlı sorgumda bitki boyunun 262 ile $345 \mathrm{~cm}$ arasında değiştiğini ifade etmişlerdir. Acar ve ark. (2009) ortalama bitki boyunu $223.87 \mathrm{~cm}$ olarak tespit etmişlerdir. Kara ve ark. (2019) ise bitki boyunun 185.4 ile 281.0 arasında değiştiğini belirterek daha düşük bitki boyu değerleri bildirmişlerdir.

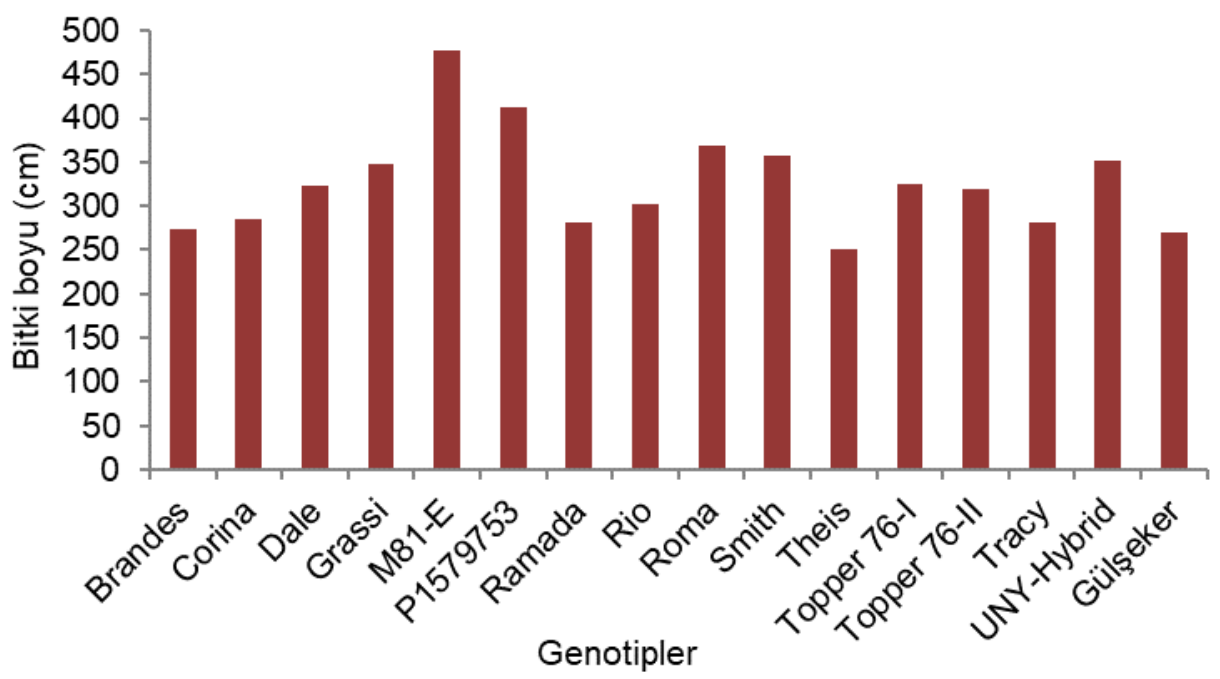

Şekil 1. Tatlı sorgum genotiplerinin bitki boyu değerleri.

Figure 1. Plant height values of sweet sorghum genotypes.

\section{Sap Kalınlığ $(\mathbf{m m})$}

Yapılan varyans analizine göre Harran Ovası ana ürün koşullarında denenen tatlı sorgum genotipleri arasında sap kalınlığı bakımından \%1 düzeyinde istatiksel olarak önemli farklıık tespit edilmiştir $(P \leq 0.01)$. 
En yüksek sap kalınlığı değeri $27.99 \mathrm{~mm}$ ile Corina çeşidinde, en düşük değer ise $19.55 \mathrm{~mm}$ olarak Roma çeşidinde saptanmıştır. Çizelge 3'de sap kalınlıklarını incelediğimizde ortalama sap kalınlığı değerinin 23.65 mm olduğu görülmektedir. Sap kalınlığı bakımından genotipler arasında varyasyon görülmüştür. Bu farklılık genotipik faktörlerden kaynaklanabilir. Tatlı sorgumda birim alandaki yeşil yem ve silaj miktarının fazla olmasına sap kalınlığı katkı sağlayabilir. Ancak sap kalınlığının artması yemdeki lignin ve selüloz miktarını artırarak yemin sindirilebilirliğini düşürebilir.

Bazı araştırıcılar bulgularımızdan daha düşük sap kalınlığı değerleri bildirmişlerdir. Çoban ve Acar (2018) Konya'da yaptıkları bir çalışmada sap kalınlığını 14.49-16.55 mm olarak tespit etmişlerdir. Başaran (2011) sap kalınlığının 11-16 mm arasında, Kara ve ark. (2019) sap kalınlığını 16.69 ile $19.23 \mathrm{~mm}$ arasında değiştiğini belirtmişlerdir. Yıldız ve ark. (2018) ise sap kalınlığını 10.47 ile 12.49 mm arasında değiştiğini bulmuşlardır.

\section{Sap Oranı (\%)}

Harran Ovası ana ürün koşullarında denenen tatlı sorgum genotipleri arasında sap oranı bakımından \%1 düzeyinde istatiksel olarak önemli farklılık bulunmuştur $(P \leq 0.01)$.

Sap oranı \%74.72 ile Ramada çeşidinde en düşük, \%91.49 ile Tracy çeşidinde en yüksek bulunmuştur. Ortalama sap oranı değeri ise \%84.06 olarak hesaplanmıştır. Yem kalitesi açısından sap oranı değerinin düşük olması, sap ve tane oranlarının ise yüksek olması istenmektedir. Sap oranı yüksek olduğunda lignin ve selüloz oranı arttığından hazım olabilir kuru madde miktarı azalmaktadır. Bu durumda yem kalitesi düşmektedir.

Ramada, P1579753, M83-E ve Corina genotiplerinin sap oranı değerleri deneme ortalamasının altında diğerlerine göre daha düşük olarak belirlenmiştir. Diğer genotiplerde ise sap oranı değerleri \%80'nin üzerinde bulunmuştur. Daniel ve ark. (2017) Dale genotipi için sap oranını \%86.6, M81-E genotipi için \%85.1, Theis genotipi için ise \%88.3 olarak saptamışlardır.

Çizelge 3. Çiçeklenme süresi, bitki boyu, sap kalınlığı ve sap oranı değerleri ve oluşan istatistiksel gruplar. Table 3. Flowering duration, plant height, stem diameter and stem ratio values and statistical groups.

\begin{tabular}{|c|c|c|c|c|}
\hline Genotipler & $\begin{array}{l}\text { Çiçeklenme süresi } \\
\text { (gün) }\end{array}$ & $\begin{array}{l}\text { Bitki boyu } \\
\text { (cm) }\end{array}$ & $\begin{array}{l}\text { Sap kalınlığı } \\
(\mathbf{m m})\end{array}$ & $\begin{array}{l}\text { Sap oranı } \\
(\%)\end{array}$ \\
\hline 1. Brandes & $106.00 \mathrm{ab}$ & $272.96 \mathrm{efg}$ & $26.47 \mathrm{abc}$ & $81.38 \mathrm{efg}$ \\
\hline 2. Corina & $98.60 \mathrm{~cd}$ & 284.16 efg & $27.99 a$ & $77.83 \mathrm{gh}$ \\
\hline 3. Dale & $80.00 \mathrm{ft}$ & $323.00 c-f$ & $26.76 \mathrm{abc}$ & $87.79 a-d$ \\
\hline 4. Grassi & $98.00 \mathrm{~cd}$ & $347.33 \mathrm{~cd}$ & $25.76 \mathrm{a}-\mathrm{d}$ & $87.36 \mathrm{bcd}$ \\
\hline 5. $M 81-E$ & $101.30 \mathrm{bc}$ & $476.30 \mathrm{a}$ & $23.69 c-f$ & $79.28 \mathrm{~g}$ \\
\hline 6. P1579753 & $99.30 \mathrm{~cd}$ & $411.53 b$ & $20.09 \mathrm{fg}$ & $77.75 \mathrm{gh}$ \\
\hline 7. Ramada & $99.60 \mathrm{c}$ & 280.66 efg & $20.08 \mathrm{fg}$ & $74.72 \mathrm{~h}$ \\
\hline 8. Rio & $88.60 \mathrm{e}$ & $302.10 \mathrm{~d}-\mathrm{g}$ & $23.20 c-f$ & $90.76 \mathrm{ab}$ \\
\hline 9. Roma & $97.00 \mathrm{~cd}$ & 367.86 bc & $19.55 \mathrm{~g}$ & $85.14 \mathrm{cde}$ \\
\hline 10. Smith & $100.00 \mathrm{c}$ & $357.10 \mathrm{bcd}$ & $21.05 \mathrm{efg}$ & 83.99 def \\
\hline 11. Theis & $80.60 \mathrm{f}$ & $250.80 \mathrm{~g}$ & $24.07 \mathrm{~b}-\mathrm{e}$ & $90.18 \mathrm{ab}$ \\
\hline 12. Topper 76-I & $108.00 \mathrm{a}$ & 325.90 cde & $22.58 \mathrm{~d}-\mathrm{g}$ & 83.97 def \\
\hline 13. Topper 76-II & $94.00 \mathrm{de}$ & $318.76 c-f$ & $23.56 c-f$ & $84.13 \mathrm{de}$ \\
\hline 14. Tracy & $101.00 \mathrm{bc}$ & $281.53 \mathrm{efg}$ & $25.57 \mathrm{a}-\mathrm{d}$ & $91.49 \mathrm{a}$ \\
\hline 15. UNL-Hybrid-3 & $100.30 \mathrm{c}$ & $352.53 \mathrm{~cd}$ & 20.46 efg & $80.10 \mathrm{fg}$ \\
\hline 16. Gülşeker & $77.60 \mathrm{f}$ & $269.36 \mathrm{fg}$ & $27.60 \mathrm{ab}$ & $89.11 \mathrm{abc}$ \\
\hline Ortalama & 95.60 & 326.37 & 23.65 & 84.06 \\
\hline LSD & 5.505 & 0.5602 & 3.6300 & 3.9912 \\
\hline Önemlilik & $\star *$ & $* *$ & $\star *$ & $\star *$ \\
\hline
\end{tabular}

$+;$ Aynı harf ile gösterilen değerler arasında Duncan testine göre $P \leq 0.05$ seviyesinde istatistiksel olarak önemli fark yoktur.

**; $P \leq 0.01$ düzeyinde önemli.

\section{Yaprak Oranı (\%)}

Varyans analizine göre test edilen tatlı sorgum genotipleri arasında yaprak oranı bakımından istatiksel olarak 0.01 önem düzeyinde farklılık olduğu tespit edilmiştir $(P \leq 0.01)$. Yaprak oranı tatlı sorgum genotiplerinde \%6.23 ile \%20.98 arasında değişmiş̧ir (Çizelge 4). Ortalama yaprak oranı değeri \%11.94 olarak hesaplanmıştır. Genotipler arasında yaprak oranının en az olduğu değer \%6.23 ile Rio, \%6.36 ile Theis ve \%6.56 ile Tracy genotiplerinde görülmüştür. Yaprak oranının en fazla olduğu değerler ise \%20.98 ve \%17.64 ile Ramada ve Corina genotiplerinde belirlenmiştir. Yem kalitesi bakımından yaprak oranının yüksek olması istenmektedir. Yaprak oranı arttığında yemin sindirilebilirliği ve besin değeri artmaktadır. Ramada (\%20-98), Corina (\%17.64), P1579753 (\%17.62), UNL- 
Hybrid-3 (\%15.01) ve M81-E (\%13.05) genotiplerinin yaprak oranı değerleri diğerlerine göre daha yüksek bulunmuştur.

Bulgularımıza benzer değerler Konya'da yapılan bir çalışmada yaprak oranlarını \%11.67 ile \%20.33 aralığında değiştiğini tespit eden Çoban ve Acar (2018) tarafından bildirilmiştir. Bulgularımızdan daha düşük olarak Yıldız ve ark. (2018) yaptıkları bir çalışmada en yüksek yaprak oranını \%12.99, en düşük yaprak oranının ise \%8.97 olarak bildirmişlerdir.

\section{Salkım Oranı (\%)}

Yapılan varyans analizine göre tatı sorgum genotipleri arasında salkım oranı bakımından 0.01 önem düzeyinde istatiksel açıdan farklılık olduğu tespit edilmiştir $(P \leq 0.01)$.

Genotipler arasında salkım oranının en az olduğu değer \%1.70 ile Gülşeker, en fazla olduğu değer ise \%7.65 ile M81-E genotipinde belirlenmiştir (Çizelge 4). Ortalama salkım oranı değeri ise \%3.99 olarak hesaplanmıştır. Salkım uzunluğu, salkım yan dal sayısı, salkımda tane sayısı ve salkımda tane ağırlığı yüksek olan iri taneli genotiplerin salkım oranı değerleri yüksek olmaktadır. Yem içerisinde salkım oranının yüksek olması tane oranının yüksek olması anlamına geldiğinden, yemin protein, karbonhidrat ve mineral madde içeriğinin yükselmesine neden olmaktadır. Bu nedenle kaba yem içerisinde salkım oranının ve tanenin yüksek olması pozitif avantaj sağlamaktadır. Genellikle salkım şekli ve büyüklüğü genotipik faktörlerden kaynaklanmaktadır.

Bulgularımıza benzer olarak Daniel ve ark. (2017) yaptıkları bir çalışmada Dale için salkım oranını \%2.5, M81-E için \%2.9, Theis için ise \%2.8 olarak saptamışlardır. Bulgularımızdan daha yüksek değerler olarak Yıldız ve ark. (2018) en yüksek salkım oranını \%38.60, en düşük salkım oranını ise \%19.30 olarak bulmuşlardır.

Çizelge 4. Yaprak oranı, salkım oranı, biyokütle verimi ve kuru madde verimi değerleri ve istatistiki gruplar. Table 4. Leaf ratio, panicle ratio, biomass yield and dry matter yield values and statistical groups.

\begin{tabular}{|c|c|c|c|c|}
\hline Genotipler & $\begin{array}{l}\text { Yaprak oranı } \\
(\%)\end{array}$ & $\begin{array}{l}\text { Salkım oranı } \\
(\%)\end{array}$ & $\begin{array}{l}\text { Biyokütle verimi } \\
\left(\mathrm{kg} \mathrm{da}^{-1}\right)\end{array}$ & $\begin{array}{l}\text { Kuru madde verimi } \\
\left(\mathrm{kg} \mathrm{da}^{-1}\right)\end{array}$ \\
\hline 1. Brandes & $12.90 \mathrm{cde}$ & $5.70 \mathrm{~b}$ & $9142.80 \mathrm{~g}$ & $2995.12 \mathrm{fg}$ \\
\hline 2. Corina & $17.64 \mathrm{ab}$ & $4.51 \mathrm{bcd}$ & $12761.90 \mathrm{~cd}$ & $3955.07 \mathrm{bcd}$ \\
\hline 3. Dale & 9.54 def & $2.65 \mathrm{fgh}$ & $14285.70 \mathrm{~b}$ & 3616.82 cde \\
\hline 4. Grassi & 9.62 def & $3.00 \mathrm{e}-\mathrm{h}$ & $12952.30 \mathrm{c}$ & $4246.20 \mathrm{~b}$ \\
\hline 5. $M 81-E$ & $13.05 \mathrm{~cd}$ & $7.65 \mathrm{a}$ & $16380.90 \mathrm{a}$ & $5599.35 \mathrm{a}$ \\
\hline 6. P1579753 & $17.62 \mathrm{ab}$ & $4.61 \mathrm{bcd}$ & $9714.30 \mathrm{~g}$ & $3556.67 \mathrm{de}$ \\
\hline 7. Ramada & 20.98 a & $4.29 \mathrm{~b}-\mathrm{e}$ & $7714.30 \mathrm{~h}$ & $2521.95 \mathrm{~g}$ \\
\hline 8. Rio & $6.23 \mathrm{f}$ & 2.99 e-h & 11333.30 ef & $4083.85 \mathrm{bc}$ \\
\hline 9. Roma & 11.94 cde & $2.91 \mathrm{e}-\mathrm{h}$ & $9142.80 \mathrm{~g}$ & $2980.25 \mathrm{fg}$ \\
\hline 10. Smith & 11.34 cde & $4.66 \mathrm{bcd}$ & $11619.10 \mathrm{de}$ & $3589.57 \mathrm{de}$ \\
\hline 11. Theis & $6.36 f$ & $3.44 \mathrm{~d}-\mathrm{g}$ & $16285.70 \mathrm{a}$ & 5309.26 a \\
\hline 12. Topper 76-I & $12.17 \mathrm{cde}$ & $3.84 c-f$ & $11714.30 \mathrm{cde}$ & $3589.48 \mathrm{de}$ \\
\hline 13. Topper 76-II & $10.92 \mathrm{de}$ & $4.94 \mathrm{bc}$ & $10190.50 \mathrm{fg}$ & $2580.27 \mathrm{~g}$ \\
\hline 14. Tracy & $6.56 \mathrm{f}$ & $2.14 \mathrm{gh}$ & $14666.70 \mathrm{~b}$ & $4193.36 \mathrm{~b}$ \\
\hline 15. UNL-Hybrid-3 & $15.01 \mathrm{bc}$ & $4.87 \mathrm{bcd}$ & 11714.30 cde & 3303.01 ef \\
\hline 16. Gülşeker & 9.17 ef & $1.70 \mathrm{~h}$ & 12380.90 cde & $4233.77 \mathrm{~b}$ \\
\hline Ortalama & 11.94 & 3.99 & 12000.00 & 3772.13 \\
\hline LSD & 3.79 & 1.45 & 1315.88 & 481.00 \\
\hline Önemlilik & ** & ** & ** & ** \\
\hline
\end{tabular}

†; Aynı harf ile gösterilen değerler arasında Duncan testine göre $P \leq 0.05$ seviyesinde istatistiksel olarak önemli fark yoktur.

**; $P \leq 0.01$ düzeyinde önemli.

\section{Biyokütle Verimi $\left(\mathrm{kg} \mathrm{da}^{-1}\right)$}

Tatlı sorgum genotipleri biyokütle verimi bakımından 0.01 önem düzeyinde istatistiki olarak birbirlerinden farklı bulunmuştur $(P \leq 0.01)$. Biyokütle verimi 7714.3 (Ramada) ile $16380.9 \mathrm{~kg} \mathrm{da}^{-1}(\mathrm{M} 81-\mathrm{E})$ arasında değişmiştir (Şekil 2). Çizelge 4'de biyokütle verimlerini incelediğimizde ortalama biyokütle veriminin $12000 \mathrm{~kg} \mathrm{da}^{-1}$ olduğu görülmektedir. Denemede yer alan tatlı sorgum genotiplerinin büyük çoğunluğu, $10000 \mathrm{~kg} \mathrm{da}^{-1}$ üzerinde biyokütle verimi vermiştir. Birim alan kaba yem miktarının yüksek olması arzu edilen bir durumdur. Bitki boyu uzun olan genotiplerin biyokütle verimleri de yüksek bulunmuştur.

Theis $\left(16285.7 \mathrm{~kg} \mathrm{da}^{-1}\right)$, M81-E (16380.9 kg da-1), Dale (14285.7 kg da-1), Tracy (14666.7 kg da-1) Grassi (12952.3 $\mathrm{kg} \mathrm{da}^{-1}$ ) ve Corina (12761.9 $\mathrm{kg} \mathrm{da}^{-1}$ ) diğer genotiplere göre daha yüksek biyokütle verimi değerleri vermişlerdir. 
Bulgularımıza benzer olarak Claassen ve ark., (2004), Yunanistan'da Keller sorgum çeşidi ile yaptıkları çalışmada $12600 \mathrm{~kg} \mathrm{da}^{-1}$ biyokütle elde edildiği belirtmişlerdir.

Bulgularımızdan daha düşük değerler bazı araştıııılar tarafından bildirilmiştir. Başaran (2011) biyokütle verimini $996.1-4453 \mathrm{~kg} \mathrm{da}^{-1}$ aralığında, Çoban ve Acar (2018) ise Konya'da yaptıkları bir çalışmada en yüksek biyokütle veriminin $9400.67 \mathrm{~kg} \mathrm{da}^{-1}$, en düşük biyokütle veriminin $7038.33 \mathrm{~kg} \mathrm{da}^{-1}$ olduğunu belirtmişlerdir. Farklı ekolojilerde farklı sonuçlar elde edilmesi, genotipik farklıık yanında iklim ve toprak farklılığından kaynaklanabilir.

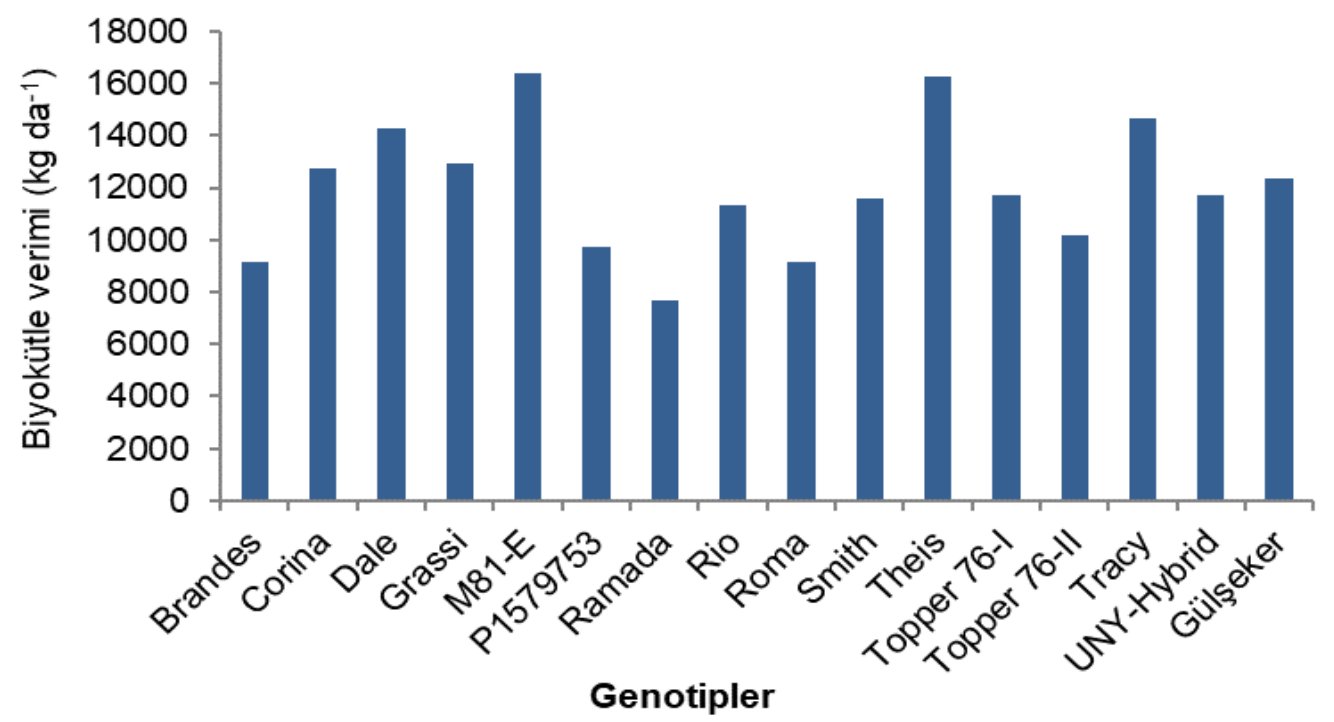

Şekil 2. Tatlı sorgum genotiplerinin biyokütle verimi değerleri.

Figure 2. Biomass yield values of sweet sorghum genotypes.

\section{Kuru Madde Verimi ( $\left.\mathrm{kg} \mathrm{da}^{-1}\right)$}

Varyans analiz sonuçlarına göre tatlı sorgum genotipleri arasında kuru madde verimi bakımından 0.01 önem düzeyinde istatiksel açıdan farklılık olduğu tespit edilmiştir ( $P \leq 0.01)$.

Kuru madde verimi en düşük $2521.95 \mathrm{~kg} \mathrm{da}^{-1}$ ile Ramada genotipinde, en yüksek $5599.35 \mathrm{~kg} \mathrm{da}^{-1}$ ile M81-E genotipinde tespit edilmiştir (Şekil 3). Ortalama kuru madde verimi ise $3772.13 \mathrm{~kg} \mathrm{da}^{-1}$ olarak hesaplanmıştır (Çizelge 4). Theis (5309.26 kg da-1), Grassi (4246.20 kg da-1), Gülşeker (4233.77 kg da-1), Tracy (4193.36 kg da-1), Rio $\left(4083.85 \mathrm{~kg} \mathrm{da}^{-1}\right)$ ve Corina $\left(3955.07 \mathrm{~kg} \mathrm{da}^{-1}\right)$ genotipleri yüksek kuru madde verimleri ile dikkat çekmektedir.

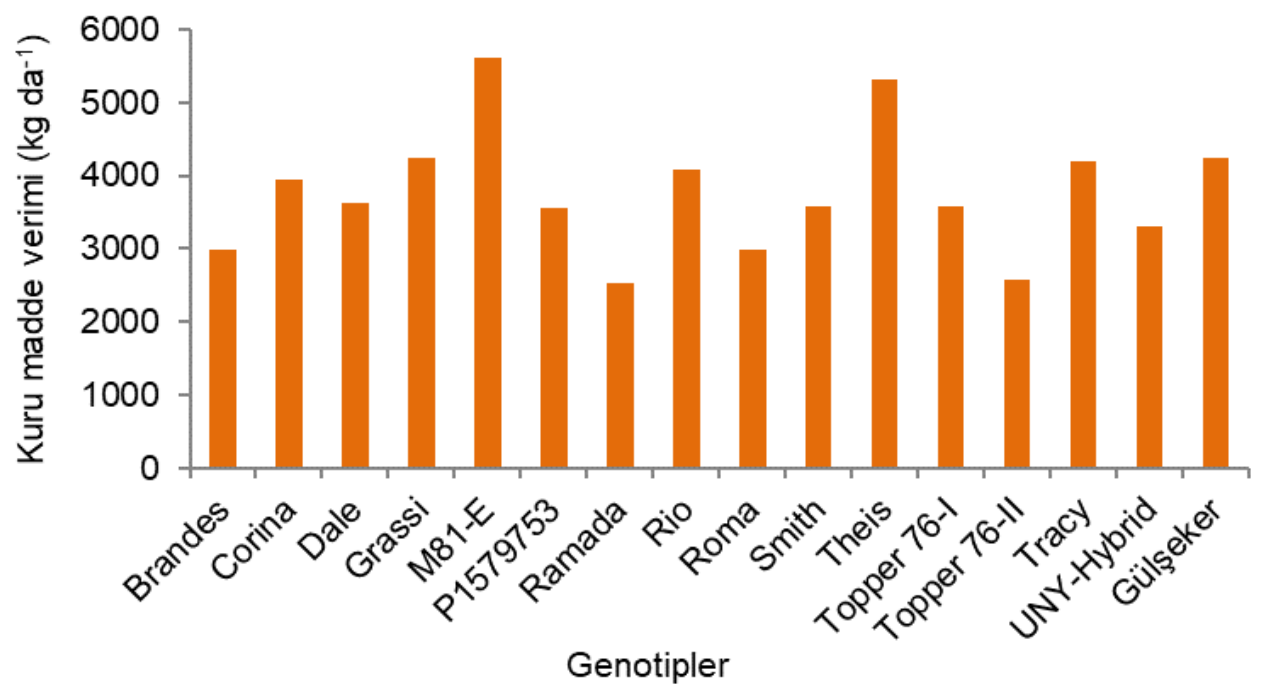

Şekil 3. Tatlı sorgum genotiplerinin kuru madde verimi değerleri.

Figure 3. Dry matter yield values of sweet sorghum genotypes.

Genel olarak birim alandaki kuru madde veriminin yüksek olması, yemin bünyesindeki besin ve mineral maddelerinin yüksek olduğunun göstergesidir. Bazı araştıııılar sorgum bitkisinde bulgularımızdan daha düşük 
kuru madde verimi değerleri bildirmişlerdir. Zhao ve ark. (2009) kuru madde veriminin 1320 ile $2710 \mathrm{~kg} \mathrm{da}^{-1}$ arasında değiştiğini belirtmiş̧ir. Çoban ve Acar (2018) 1794.67 ile $2581.00 \mathrm{~kg} \mathrm{da}^{-1}$ arasında değişen kuru madde verimi saptamışlardır. Tuğay (2009) kuru madde verimini 1300.1 ile $1544.8 \mathrm{~kg} \mathrm{da}^{-1}$ olarak bulmuştur. Kara ve ark. (2019) ortalama kuru madde verimini $1334.53 \mathrm{~kg} \mathrm{da}^{-1}$ olarak tespit etmişlerdir. Geren ve ark. (2019) ise kuru madde veriminin 992-1204 $\mathrm{kg} \mathrm{da}^{-1}$ arasında değiştiğini saptamışlardır. Araştırmamızdaki kuru madde verimi değerlerinin yüksek olması kullanılan çeşitlerin biyokütle verimlerinin yüksek olmasından kaynaklanmaktadır.

\section{Ham Kül Oranı (\%)}

Ham kül oranı, yem maddesinin inorganik maddelerden oluşmuş kül miktarının \% olarak ifade edilmesidir. Yemdeki ham kül oranı yemin mineral madde kapsamı hakkında bilgi vermektedir. Varyans analiz sonuçlarına göre tatlı sorgum genotipleri arasında ham kül oranı bakımından istatiksel açıdan 0.01 önem düzeyinde farklılık olduğu tespit edilmiştir $(P \leq 0.01)$.

Genotipler arasında ham kül oranı \%6.54 (Rio) ile \%10.1 (P1579753) arasında değişmiştir. Ortama ham kül oranı değeri \%7.78 olarak hesaplanmıştır. P1579753, Gülşeker, Topper 76-II, Grassi ve Tracy genotiplerinde ham kül oranı yüksek bulunmuştur. Benzer bulgular ham kül oranının \%6.15 ile \%13.08 arasında değiştiği bildiren Chakravarthi ve ark., (2017) ve \%5.62 ile \%6.76 arasında bildiren Kumari ve ark. (2013) tarafından bildirilmiştir.

\section{NDF - Neutral Detergent Fiber (\%)}

Tatlı sorgum genotipleri arasında NDF bakımından istatiksel olarak 0.01 önem düzeyinde farklılık olduğu tespit edilmiştir ( $\mathrm{P} \leq 0.01)$. NDF değerleri \%55.35 (Gülşeker) ile \%43.68 (Ramada) arasında değişmiştir. Ortalama NDF değeri ise \%48.54 olarak tespit edilmiştir.

NDF, bitki hücre duvarı yapısında bulunan selüloz, hemiselüloz, lignin, kütin ve çözünmeyen protein miktarını ifade etmektedir. Yemdeki NDF oranı azaldıkça hayvanın yemden faydalanma oranı artmaktadır. NDF değerinin \%40'ın altında olması istenmektedir (Van Soest, 1994). Denemede yer alan tatlı sorgum genotiplerinin tamamı \%40'ın üzerinde NDF değerleri vermiştir. Ancak Roma (\%44.48), Ramada (\%43.68), Theis (\%45.71) genotipleri diğerlerine göre daha düşük NDF değerleri vererek istenilen NDF değerlerine yaklaşmışlardır.

Bulgularımıza benzer olarak Machado ve ark. (2012) tatlı sorgumda NDF değerinin \%45.9 ile \%54.9 arasında, Mahmood ve ark., (2013) ise tatlı sorgum çeşitlerinde NDF değerlerinin \%47.9 ile \%60.6 arasında değiştiğini bildirmektedirler. Junior ve ark. (2015) \%43.63 ile \%48.32 arasında değişen NDF değerleri ile bulgularımıza göre daha düşük NDF değerleri bildirmişlerdir. Bulgularımızdan daha yüksek değerler ise bazı araştırmacılar tarafından elde edilmiştir. Kumari ve ark. (2013) \%75.4 ile \%73.54 arasında değişen daha yüksek NDF değerleri belirtmişlerdir. Mosali ve ark. (2013) NDF değerinin \%62.2 ile \%66.3 arasında olduğunu, Khota ve ark. (2000) ise NDF değerlerini \%69.46 olarak bulduklarını belirtmişlerdir.

\section{ADF-Acid Detergent Fiber (\%)}

Yapılan varyans analizine göre denenen tatlı sorgum genotipleri arasında ADF bakımından istatiksel açıdan 0.01 önem düzeyinde farklılık olduğu tespit edilmiştir $(P \leq 0.01)$.

ADF değerleri \%27.09 (Roma) ile \%34.76 (Gülşeker) arasında, ortalama ADF değeri ise \%30.03 olarak tespit edilmiştir. ADF bitki hücre duvarında bulunan selüloz, lignin ve çözünmeyen protein miktarını ifade etmektedir. Yemde ADF oranı arttıkça, sindirim oranı azalmaktadır. Yemdeki ADF değerinin \%31'den düşük olması istenmektedir (Van Soest, 1994). Denemede yer alan tatlı sorgum genotiplerinin büyük çoğunluğunun ADF değerleri \%30'un altında tespit edilmiştir. Özellikle Roma, Brandes, Ramada, M81-E, Theis ve Corina genotiplerinin ADF değerleri diğerlerinden daha düşük seviyede bulunmuştur. Denemede yer alan tatlı sorgum genotipleri ADF değerlerinin kabul edilebilir olduğu söylenebilir.

Araştırma bulgularımıza benzer olarak Junior ve ark. (2015) sorgumda ADF değerinin \%24.01 ile \%27.69 arasında olduğunu, Mosali ve ark. (2013) ADF değerinin \%39.2 olduğunu belirtmişlerdir. Çeşitlere göre değişmekle birlikte tatı ı sorgum ADF değerinin \%27.9-40.88 arasında değiştiği bildirilmektedir (Mahmood ve ark. 2013). Tatı sorgumda daha yüksek ADF değeri \%43.5 olarak (Khota ve ark., 2000), \%45.9-46.82 olarak (Kumari ve ark., 2013) ve \%46.75 olarak (Vidya ve ark., 2016) bildirilmiştir.

\section{ADL-Acid Detergent Lignin (\%)}

Tatlı sorgum genotipleri arasında ADL bakımından istatistiki olarak 0.01 önem düzeyinde farklılık olduğu tespit edilmiştir $(P \leq 0.01)$. En düşük $A D L$ değeri \%5.51 (Brandes), en yüksek değer \%7.59 (Gülşeker) ve ortalama $A D L$ değeri ise \%6.23 olarak belirlenmiştir. ADL değeri bitki hücre duvarında yer alan ve asit deterjan solüsyonlarda çözünmeyen lignin miktarını ifade etmektedir. Lignin hayvanların yem sindirme yeteneğini etkileyen bir bileşiktir. 
Bitkinin lignin içeriği bitki olgunlaştıkça artmakta ve yemin sindirilebilirliği ve yarayışılıı̆ı azalmaktadır. ADL değerinin düşük olması arzu edilmektedir. Brandes, Corina, M81-E, Roma, Theis ve Topper 76-II tatlı sorgum genotiplerinin ADL değerleri diğerlerine göre daha düşük bulunmuştur. Chen ve ark., (2018) tatlı sorgum bitkisinde ADL değerinin \%8.3 ile \%8.6 arasında değiştiğini belirterek bulgularımızdan daha yüksek değerler bildirmişlerdir.

\section{Hemiselüloz ve Selüloz (\%)}

Varyans analiz sonuçlarına göre tatlı sorgum genotipleri arasında hemiselüloz ve selüloz oranı bakımından 0.01 önem düzeyinde istatiksel açıdan farklılık olduğu tespit edilmiştir $(P \leq 0.01)$.

Genotiplerin hemiselüloz değerleri \%15.59 (Ramada) ile \%20.59 (Gülşeker) arasında, ortalama hemiselüloz değeri ise \%18.51 olarak tespit edilmiştir. Denemede kullanılan tatı sorgum genotiplerinden Ramada (\%15.51), Rio (\%16.72), Tracy (\%17.16), Roma (\%17.39) ve Theis (\%17.42) diğerlerine göre daha düşük hemiselüloz değerleri vermişlerdir.

Selüloz oranı genotipler arasında \%21.31 (Roma) ile \%27.17 (Gülşeker) arasında değişmiş ve ortalama selüloz oranı \%23.80 olarak saptanmıştır. Roma (\%21.31), Ramada (\%21.61), Brandes (\%22.50), Corina (\%22.98), M81-E (\%23.03) ve Rio (\%23.17) tatlı sorgum genotiplerinin selüloz değerleri diğerlerine oranla daha düşük gözlenmiştir.

Araştırma bulgularımıza benzer şekilde tatlı sorgum çeşitlerinde hemiselülozun \%11.73 ile \%17.20 arasında, selülozun ise \%20.18 ile \%26.14 arasında değiştiği bildirilmektedir (Khalil ve ark., 2015).

Büyüme başlangıcındaki genç ve taze bitkilerde selüloz ve hemiselüloz miktarı daha düşük iken, vejetasyonun ilerlemesi ve olgunlaşmanın artmasına paralele olarak bitkideki oranları giderek artmaktadır. Sindirilebilmeleri zor olduğu için yem içerisindeki oranlarının düşük olması istenmektedir.

Çizelge 5. Kül, NDF, ADF, ADL, hemiselüloz ve selüloz oranı değerleri. Table 5. Ash, NDF, ADF, ADL, hemicellulose and cellulose ratio values.

\begin{tabular}{lllllll}
\hline Genotipler & $\begin{array}{l}\text { Ham kül } \\
(\%)\end{array}$ & $\begin{array}{l}\text { NDF } \\
(\%)\end{array}$ & $\begin{array}{l}\text { ADF } \\
\text { (\%) }\end{array}$ & $\begin{array}{l}\text { ADL } \\
\text { (\%) }\end{array}$ & $\begin{array}{l}\text { Hemiselüloz } \\
\text { (\%) }\end{array}$ & $\begin{array}{l}\text { Selüloz } \\
\text { (\%) }\end{array}$ \\
\hline 1. Brandes & $7.25 \pm 0.36^{*}$ & $47.58 \pm 2.86$ & $28.01 \pm 1.58$ & $5.51 \pm 0.31$ & $19.58 \pm 2.00$ & $22.50 \pm 1.45$ \\
2. Corina & $7.12 \pm 0.91$ & $46.87 \pm 1.95$ & $28.66 \pm 1.90$ & $5.68 \pm 0.76$ & $18.21 \pm 0.64$ & $22.98 \pm 1.41$ \\
3. Dale & $6.86 \pm 0.65$ & $49.86 \pm 2.07$ & $31.74 \pm 0.56$ & $6.45 \pm 0.80$ & $18.12 \pm 1.64$ & $25.29 \pm 0.85$ \\
4. Grassi & $8.56 \pm 0.63$ & $51.66 \pm 3.82$ & $32.25 \pm 2.28$ & $6.25 \pm 0.21$ & $19.40 \pm 2.33$ & $26.01 \pm 2.24$ \\
5. M81-E & $7.70 \pm 1.20$ & $47.85 \pm 2.85$ & $28.56 \pm 2.12$ & $5.52 \pm 0.72$ & $19.29 \pm 0.84$ & $23.03 \pm 1.54$ \\
6. P1579753 & $10.1 \pm 1.05$ & $52.65 \pm 3.74$ & $32.96 \pm 2.94$ & $6.61 \pm 0.64$ & $19.69 \pm 1.42$ & $26.35 \pm 2.59$ \\
7. Ramada & $7.35 \pm 0.78$ & $43.68 \pm 2.77$ & $28.08 \pm 2.12$ & $6.47 \pm 0.65$ & $15.59 \pm 1.61$ & $21.61 \pm 1.49$ \\
8. Rio & $6.54 \pm 0.82$ & $46.63 \pm 2.51$ & $29.90 \pm 1.36$ & $6.73 \pm 0.63$ & $16.72 \pm 1.23$ & $23.17 \pm 1.27$ \\
9. Roma & $6.74 \pm 0.61$ & $44.48 \pm 4.05$ & $27.09 \pm 3.02$ & $5.78 \pm 1.18$ & $17.39 \pm 1.61$ & $21.31 \pm 1.91$ \\
10. Smith & $6.98 \pm 0.94$ & $48.93 \pm 0.85$ & $29.68 \pm 1.09$ & $6.68 \pm 0.75$ & $19.25 \pm 0.39$ & $23.00 \pm 0.59$ \\
11. Theis & $6.93 \pm 0.37$ & $45.71 \pm 2.58$ & $28.29 \pm 1.86$ & $5.62 \pm 0.42$ & $17.42 \pm 1.76$ & $22.67 \pm 1.74$ \\
12. Topper 76-I & $7.53 \pm 1.29$ & $47.40 \pm 4.09$ & $29.30 \pm 3.52$ & $6.02 \pm 0.65$ & $18.10 \pm 0.68$ & $23.29 \pm 2.97$ \\
13. Topper 76-II & $9.00 \pm 0.83$ & $48.84 \pm 2.00$ & $29.19 \pm 1.92$ & $5.68 \pm 0.19$ & $19.65 \pm 0.85$ & $23.51 \pm 1.73$ \\
14. Tracy & $8.33 \pm 1.70$ & $48.00 \pm 4.84$ & $30.84 \pm 3.79$ & $7.10 \pm 1.71$ & $17.16 \pm 1.75$ & $23.74 \pm 2.15$ \\
15. UNL-Hybrid-3 & $7.72 \pm 1.12$ & $51.11 \pm 3.28$ & $31.10 \pm 3.45$ & $5.99 \pm 0.54$ & $20.00 \pm 0.98$ & $25.11 \pm 3.00$ \\
16. Gülşeker & $9.66 \pm 1.95$ & $55.35 \pm 4.95$ & $34.76 \pm 2.19$ & $7.59 \pm 1.86$ & $20.59 \pm 3.11$ & $27.17 \pm 0.68$ \\
Ortalama & 7.78 & 48.54 & 30.03 & 6.23 & 18.51 & 23.80 \\
Önemlilik & $* *$ & $* *$ & $* *$ & $* *$ & $* *$
\end{tabular}

*; Ortalama değerler ile standart sapma değerlerini ifade etmektedir $(\dot{X}, \pm \sigma)$.

$\star * ;$ Genotipler arasındaki istatistiki önemi gösterir $P \leq 0.01$.

\section{SONUÇ}

Araştırma sonuçlarına göre; tatlı sorgum genotiplerinde gözlenen çiçeklenme süresi 77.6 ile 108.0 gün, bitki boyu $250.80 \mathrm{~cm}$ ile $476.30 \mathrm{~cm}$, sap kalınlığı $19.55 \mathrm{~mm}$ ile $27.99 \mathrm{~mm}$ arasında değişmiştir. Sap oranı \%74.72 ile \%91.49, yaprak oranı \%6.36 ile \%20.98, salkım oranı \%1.70 ile \%7.65 arasında bulunmuştur.

Tatlı sorgum genotiplerinin biyokütle verimi 7714.3 ile $16380.9 \mathrm{~kg} \mathrm{da}^{-1}$, kuru madde verimi 2521.95 ile 5599.35 $\mathrm{kg} \mathrm{da}^{-1}$, ham kül oranı ise \%6.54 ile \%10.1 arasında değişmiştir.

NDF değerleri \%55.35 ile \%43.68, ADF değerleri \%27.09 ile \%34.76, ADL değerleri \%5.51 ile \%7.59, hemiselüloz değerleri \%15.59 ile \%20.59, selüloz oranı ise \%21.31 ile \%27.17 arasında bulunmuştur.

Tatlı sorgum bitkisinin araştırma alanı GAP bölgesine ve benzer iklim koşullarına adaptasyon kabiliyetlerinin yüksek olduğu, benzer ekolojilerde rahatıkla yetiştirilebileceği ve yüksek verim alınabileceği belirlenmiştir. 

ve Yem Kalitesinin Belirlenmesi

Biyokütle verimi, kuru madde verimi, NDF ve ADF değerleri göz önüne alındığında M81-E, Theis, Tracy ve Dale tatlı sorgum genotiplerinin verim ve yem kalite değerlerinin diğerlerine oranla daha iyi olduğu görülmüştür. Ancak diğer tatlı sorgum genotiplerinin çoğu da tatminkâr verim ve kalite düzeylerine ulaşmıştır. Tatıı sorgum bitkisinin ülkemiz yem açığını kapatmada yem kaynağı olarak kullanılabileceği belirlenmiştir. Tatlı sorgum bitkisinin ülkemizin değişik bölgelerinde uzun yıllar denenerek yem olarak kullanılabilme olanaklarının belirlenmesi faydalı olacaktır.

\section{ÇIKAR ÇATIŞMASI}

Makale yazarları aralarında herhangi bir çıkar çatışması olmadığını beyan ederler.

\section{YAZAR KATKISI}

AÖ çalışmayı tasarlayarak denemeyi kurmuş, arazi çalışmalarını yürütmüş ve makaleyi yazmıştır. AGÖ kalite laboratuvar analizlerini ve istatistiki analizleri yapmıştır. DD arazi çalışmalarını yürütmüş, gözlem değerlerini almış ve kaynak taraması yapmıştır.

\section{KAYNAKLAR}

Abah, C. R., Ishiwu, C. N., Obiegbuna, J. E., \& Oladejo, A. A. (2020). Sorghum grains: nutritional composition, functional properties and its food applications. European Journal of Nutrition \& Food Safety, 12(5), 101-111.

Acar, R., \& Akgün, N. (2009). Şeker darııının (Sorgum bicolor (L.) Moench var. saccharatum) yeşil ot verim öğelerine farklı azot dozlarının etkisi. Türkiye 8. Tarla Bitkileri Kongresi, Hatay.

Anonim, (2019). Şanlıurfa Meteoroloji Müdürlüğü 2019 Yılı Bülteni, Şanlıurfa.

Avcı, S., Ileri, O., \& Kaya, M. D. (2018). Sorgum'da farklı tohum miktarlarının verim öğeleri ile çimlenme özellikleri üzerine etkileri. Süleyman Demirel Üniversitesi Fen Bilimleri Enstitüsü Dergisi, 22(2), 979-985.

Başaran, R. (2011). Bartın'da sorgum (Sorghum bicolor (L.) Moench) çeşitlerinin ikinci ürün silajlık olarak yetiştirilmesi. Yüksek Lisans Tezi, Selçuk Üniversitesi, Fen Bilimleri Enstitüsü, Konya.

Chakravarthi, M. K., Reddy, Y.R., Rao, K. S., Ravi, A., Punyakumari, B., \& Ekambaram B. (2017). A study on nutritive value and chemical composition of sorghum fodder. International Journal of Science, Environment and Technology, 6(1), 104- 109.

Claassen, P. A. M., Vrije, T., \& Budde, M. A. W. (2004). Biological hydrogen production from sweet sorghum by thermophilic bacteria. 2nd World Conferance on Biomass for Energy. Industry and Climate Protection. Rome, Italy.

Chen, L., Li, J., Dong, Z., Yuan, X., \& Shao, T. (2018). Effects of applying oil-extracted microalgae on the fermentation quality, feed-nutritive value and aerobic stability of ensiled sweet sorghum. Journal of the Science of Food and Agriculture, 98, 4462-4470.

Çoban, Ü., \& Acar, R. (2018). Farklı tohum yataklarına ekilen sorgum sudan otu çeşitlerinin verim ve bazı kalite özelliklerinin belirlenmesi. Bahri Dağdaş Bitkisel Araştırma Dergisi, 7(2), 32-38.

Daniel, E. E., Ajit, K. M., Mark, L. Jr. A., Danielle, D. B., Umakanta, J., Gerald, J. W., \& Archie, L. W. (2017). Evaluation of three cultivars of sweet sorghum as feedstocks for ethanol production in the Southeast United States. Heliyon, 3, 1-18.

Dinç, U., Şenol, S., Sayın, M., Kapur, S., \& Güzel, N. (1988) Güneydoğu Anadolu Bölgesi Toprakları (GAT) I. Harran Ovası, TÜBiTAK, Tarım Ormancılık Araştırma Grubu, Güdümlü Araşıırma Projesi Kesin Sonuç Raporu, TAOG, 534, Adana.

Efe, E., Bek, Y., \& Şahin, M., 2000. İstatistik Yöntemler II. T.C. Kahramanmaraş Sütçü imam Üniversitesi Rektörlüğü Yayın No:10, P.214. K. Maras.

Geren, H., Kır, B., \& Kavut, Y. T. (2019). Farklı biçim zamanlarının tatlı darı (Sorgum bicolor var. saccharatum) çeşitleri üzerinde verim ve bazı yem kalite unsurlarına etkisi. Ege Üniversitesi Ziraat Fakültesi Dergisi, 56, 249-255.

Girgin, V.Ç. (2012). Bornova koşullarında ikinci ürün olarak yetiştirilen tatlı sorgum (Sorghum bicolor L.)'da farklı azot dozlarının bazı tarımsal ve teknolojik özelliklere etkisi üzerinde araştırmalar. Yüksek Lisans Tezi, Ege Üniversitesi, Fen Bilimleri Enstitüsü; İzmir.

Grassi, G. (2021). Sweet sorghum: One of the best world food-feed-energy crop. https://www.eubia.org/cms/wpcontent/uploads/2002/01/images_projects_old_LAMNET_-_sweet_sorghum.pdf, Erişim tarihi: 19 Haziran 2021. 
Öktem ve ark., Geç Olum Süresine Sahip Bazı Tatlı Sorgum (Sorghum bicolor var. saccaharatum (L.) Mohlenbr.) Genotiplerinin Biyokütle Verimi ve Yem Kalitesinin Belirlenmesi

Junior, M. A. P. O., Retore, M., Manarelli, D. M., Souza, F. B., Ledesma, L. L. M. \& Orrico, A. C. A. (2015). Forage potential and silage quality of four varieties of saccharine sorghum, Pesquisa Agropecuária Brasileira, 50(120), 1-7.

Kara, E., Sürmen, M., \& Erdoğan, H. (2019). Katı biyogaz atığı uygulamalarının sorgum ve sorgum x sudanotu melezi bitkilerinde yem verimi ve kalitesi üzerine etkileri. Uluslararası Tarım ve Yaban Hayatı Bilimleri Dergisi, 5, 355-361.

Khalil, S. R. A., Abdelhafez, A. A., \& Amer, E. A. M. (2015). Evaluation of bioethanol production from juice and bagasse of some sweet sorghum varieties. Annals of Agricultural Science, 60(2), 317-324.

Khota, W., Pholsen, S., Higgs, D., \& Cai, Y. (2000). Fermentation quality and in vitro methane production of sorghum silage prepared with cellulase and lactic acid bacteria. Asian-Australasian Journal of Animal Sciences, 30, 1568-1574.

Kumari, N. N., Reddy, Y. R., Blümmel, M., Nagalakshmi, D., \& Monica, T. (2013). Effect of feeding sweet sorghum bagasse silage with or without chopping on nutrient utilization in deccani sheep. Animal Nutrition and Feed Technology, 13, $243-249$.

Machado, L. C., Ferreira, W. M., \& Scpinello, C. (2012). Apparent digestibility of simplified and semi-simplified diets, with and without addition of enzymes, and nutritional value of fibrous sources for rabbits. RevistaBrasileira de Zootecnia, 41,16621670.

Mahmood, A., Ullah, H., ljaz, M., Javaid, M. M., Shahzad, A. N., \& Honermeier, B. (2013). Evaluation of sorghum hybrids for biomass and biogas production. Australian Journal of Crop Science, 7(10):1456-1462.

Mosali, J., Rogers, J., Huhnke, R., Bellmer, D., \& Cook, B. (2013). Effect of nitrogen fertilization timing on juice and bagasse quality of sweet sorghum for biofuel production. 19th World Congress of Soil Science, Soil Solutions for a Changing World 48, Brisbane, Australia.

Öktem, A., \& Öktem, A. G. (2018). Usage of Energy Plants as a Biofuel Source. Current Academic Studies in Agricultural Science, Ivpe, Cetinje- Montenegro.

Öktem, A., Öktem, A. G., \& Avcıoglu, E. (2018). Determination of yield and biofuel potential of some early sweet sorghum (Sorghum bicolor var. saccharatum (L.) Mohlenbr.) Genotypes. IX International Scientific Agriculture Symposium-Agrosym 2018, Bosnia and Herzegovina.

Reddy, B. V. S., Ramesh, S., Reddy, P. S., Ramaiah, B., Salimath, P. M., \& Kachapur, R. (2005). Sweet sorghum-a potential alternate raw material for bio-ethanol and bioenergy. International Sorghum and Millets Newsletter, 46, 79-86.

Salman, A., \& Budak, B. (2015). Farklı sorgum x sudanotu melezi çeşitlerinin verim ve verim özellikleri üzerine bir araştırma. Adnan Menderes Üniversitesi Ziraat Fakültesi Dergisi, 12, 93-100.

Samarth, A. G. More, D., \& Hashmi, I. (2018). Studies on physico-chemical properties and nutritional profile of sweet sorghum. International Journal of Chemical Studies, 6, 9-15.

Sluiter, A., Hames, B., Ruiz, R., Scarlata, C., Sluiter, J., \& Templeton, D. (2008) Determination of Ash in Biomass. National Renewable Energy Laboratory Analytical Procedure (LAP). Technical Report NREL/TP-510-42622.

Tuğay, M. (2009). Toprak işlemeli ve işlemesiz uygulamaların ikinci ürün sorgumun (Sorghum spp.) verim ve kalitesine etkisi. Yüksek Lisans Tezi, Selçuk Üniversitesi, Fen Bilimleri Enstitüsü, Tarla Bitkileri Anabilim Dalı, Konya.

Van Soest, P. J., Robertson, J. D., \& Lewis, B. A. (1991). Methods for dietary fiber, neutral detergent fiber and non-starch polysaccharides in relation to animal nutrition. Journal of Dairy Science, 74, 3583-3597.

Van Soest, P. J. (1994). Nutritional Ecology of the Ruminant (2nd Ed.). Ithaca, N.Y. Cornell University Press.

Vidya, B., Reddy, Y. R., Rao, D. S., Reddy, V. R., Kumari, N. N., \& Blummel, M. (2016). Effect of supplementation of concentrate to sweet sorghum bagasse with leaf residue silage on nutrient utilization and nitrogen balance in native sheep. Indian Journal Animal Research, 50 (3), 387-391.

Yıldız, D., Kaplan, M., Temizgül, R., \& Kardeş, Y. M. (2018). Farklı dozlarda uygulanan selenyumun sorgum bitkisinde tane verimi ve yem kalitesi üzerine etkisi. Mediterranean Agricultural Sciences, 31, 149-153.

Zhao, Y. L., Dolat, A., Steinberger, Y., Wanga, X., Osman, A., \& Xie, G. H. (2009). Biomass yield and changes in chemical composition of sweet sorghum cultivars grown for biofuel. Field Crops Research, 111, 55-64. 